\title{
Deliberative America
}

\author{
Peter M. Shane
}

\begin{abstract}
New books by Bruce Ackerman and James Fishkin and by Ethan J. Leib conclusively demonstrate that ambitious versions of deliberative democracy are susceptible to practical implementation in the United States. This review argues that the suggested reforms would be most potent if deployed as a simultaneous project of revitalizing both the electoral and deliberative aspects of American democratic legitimacy, and that campaigns to do so on a local level are more likely both to attract political support and achieve effectiveness than a campaign aimed at the national government.
\end{abstract}

KEYWORDS: Deliberative America, Deliberation Day, Deliberative Democracy in America, A Proposal for a Popular Branch of Government 
Deliberative America

Peter M. Shane*

Reviewing Bruce Ackerman and James S. Fishinin, Deliberation Day (New Haven: Yale University Press, 2004) and Ethan J. Leib, Deliberative Democracy in America: A Proposal for a Popular Branch of Government (University Park: Pennsylvania State University Press, 2004).

It is my experience that skeptical conversations about deliberative democracy (DD) tend to focus on three anxieties: first, that DD may be normatively wrongheaded -- it may be based on the wrong vision of what democracy should be; second, that DD cannot live up to its promise even if the underlying vision were right, DD could not fulfill it; and finally, even if DD is based on attractive values and could work in theory, it is just not susceptible to practical implementation in the United States. Two recent books have now come along, both bearing the notable stamp of New Haven democratic theory, which conclusively put the third of these worries to rest. Deliberation Day by Bruce Ackerman and James S. Fishkin and Deliberative Democracy in America by Ethan J. Leib each offers a workable blueprint for designing new American institutions that would render our democracy far more deliberative in character. They are "workable" in the sense that neither relies on budgets, logistical arrangements, or human capacities that go beyond what a determined nation could readily achieve. Whether either vision could sufficiently inspire our collective political will to attain implementation is, of course, a different question.

What the two books have most obviously in common is a belief in the democratic attractiveness of deliberation and in the ability of so-called "ordinary" citizens to participate

* Joseph S. Platt - Porter, Wright, Morris \& Arthur Professor of Law and Director, Center for Interdisciplinary Law and Policy Studies, Moritz College of Law, The Ohio State University. 
meaningfully. This common ground is not surprising. Deliberation Day draws heavily on Jim Fishkin's experience running so-called Deliberative Polls (DP's), a form of structured informed discussion among random samples of non-expert citizens that aims to determine, "What would the public think about an issue under good conditions for considering it?" (A-F 44) Fishkin and his collaborators have conducted past DP's, in part, as social science experiments, to determine the impact of the experience on participants' attitudes, information, and political preferences. The data consistently support an affirmative story about the human capacity for civil, highly participatory, successfully educative deliberation that positively affects participants' knowledge and attitudes and leads to substantial opinion shifts. Leib summarizes some of this evidence, and draws on Fishkin as a major influence in forming his own optimistic view of what non-expert citizens can achieve under good communication conditions.

Nonetheless, the books prescribe dramatically different reforms. What produces the radical differences are different implicit theories of democratic legitimacy and, in consequence, different convictions as to the steps necessary to relieve what each book takes to be the legitimacy deficit in American democracy. My aim in this review, after summarizing the Ackerman and Fishkin (A-F) and Leib proposals, will be to consider the two books' models of democratic legitimacy and to suggest how they could most profitably be integrated. A-F are persuasive in predicting that the creation of Deliberation Day would mark a significant invigoration of American representative democracy. But Leib is also persuasive in emphasizing the gap between even an invigorated representative democracy and the attainment of deeply democratic collective self-determination. If we could achieve the political will to accomplish anything along the lines that either book prescribes, it would be best to draw on the insights underlying both models and to move our democratic practice in ways that simultaneously 
strengthen both its direct and representative character.

\section{Designs for new deliberative institutions}

No brief recapitulation can do complete justice to either the A-F or Leib proposals because both books proffer their nuts-and-bolts models in such comprehensive detail as to assure the reader that the authors have neither ignored any major logistical issue nor designed a bird that can't fly. The approach is risky because it invites caviling over the details, but it generally works in both cases. The outline I am providing here is intended to convey only enough of the basic scheme of each proposal to demonstrate how the authors connect their general prescriptions to their differing diagnoses of American democracy's shortcomings.

The A-F proposal is a new national holiday -- more specifically, a two-day quadrennial holiday linked to each presidential election -- called Deliberation Day. The purpose of Deliberation Day would be to involve scientifically drawn random samples of American citizens in deliberations about two to four issues identified by the two major parties a month prior to the national holiday. A-F would find the four days necessary to create Deliberation Day and to make each presidential Election Day a two-day national holiday by canceling each year's current President's Day and hoarding the time over four years for A-F's proposed new exercise in citizen engagement.

Half the sampled population would deliberate on each of the two Deliberation Days. The format each day would involve a series of small and large group discussions. Upon arriving at their local deliberation sites, each day's participants would be split into discussion groups of 15 each. They would start by watching together a live 75-minute debate between the presidential candidates, who would focus their remarks on the parties' designated issues. In particular, the candidates would be required to respond to questions that were themselves formulated by a 
nationally drawn random sample of citizens, who would have convened two days in advance of the debate to define questions that ought to be put to the presidential contenders.

After each day's debate and a short break, the small groups would convene, with moderators, to define in each local deliberation site a series of questions that should be put to a panel of local party representatives, following up on the subjects addressed by the presidential candidates. These initial discussion sessions would last for an hour, after which all the small groups would gather in plenary session to listen to the party representatives respond to citizens' questions. Following the plenary assembly -- and lunch -- the discussants would reassemble in small groups and deliberate for another hour with the aim of identifying additional questions, either to prompt a clarification of the parties' positions or to raise issues that the candidates and their representatives neglected to address fully. These sessions would be followed by a second plenary assembly. The small groups would then reconvene a third time at the end of the day, and members would simply proceed one by one to report their major impressions of how the parties performed and whether anything they heard changed their minds about any issue under discussion. Nothing would be voted upon. At the end of the day, each participant would collect his or her stipend for participating and either attend the evening holiday fireworks planned after Day One or go home for dinner after Day Two.

The rationale behind Deliberation Day is straightforward. By ensuring that presidential elections will be accompanied by serious civic discussion about key issues, A-F hope to achieve elections in which Americans are enabled "to set their electoral choices within a publicregarding framework that makes sense of their claims to citizenship.” (A-F 38) Such elections would, in turn, create incentives for presidential candidates and political parties to be more seriously accountable to the people who cast votes. Although A-F plausibly suggest a variety of 
other virtues likely to follow from their scheme, the nub of the proposal is its potential contribution to intensifying the accountability of our elected national officials, thus invigorating the legitimating significance of our democratic elections. Deliberation Day would change our political landscape by letting elected leaders know what the American people think about issues if actually given the opportunity to become informed and to deliberate with others.

By way of sharp contrast, what Ethan Leib proposes is a significant redesign of our national government -- the addition of a fourth branch, the "popular branch" (PB) of government. Unlike DP's, which, in Jim Fishkin's words, have only "recommending force" (AF 44), the PB would allow citizens to engage directly in the enactment of laws. As Leib proposes it, the PB would comprise a series of stratified samples of eligible voters, 525 at a time, who would meet primarily in the format of 15-person "civic juries," getting together in plenary form only to get their jury "charges." Presumably, the term of each juror would be as long as it takes for his or her panel to vote on the question put to the PB.

The PB juries could provide a citizens' perspective on two kinds of questions. First, appellate courts could refer questions for PB deliberation, and the outcomes would be advisory to the courts, not binding. More often, the PB would debate proposals for specific new laws. Lawmaking proposals could be put to the PB either through a petition from a geographically well-distributed ten per cent of the relevant voting population or by a vote of the elected Houses of Congress or of the relevant state legislature. Under Leib's scheme, once the PB adopted a statute proposed either by the citizenry or by the legislature, the law would be submitted to the executive for approval or veto, just like a regular statute, although it could also be invalidated by a statute enacted by the legislative branch. A PB law would likewise be subject to judicial review. A PB statute, however, that passed muster with the other branches of government would 
be binding, not merely of recommending force.

PB continuity would be insured by an administrative body to be charged with "regulating, organizing and preparing the deliberative jury process." (Leib 14) To the extent deliberations are to focus on proposed statutes, the administrative body would oversee the drafting process and help assemble informational and factual materials to be used as a basis for citizen deliberations. This coordinating body would be headed, as Leib describes it, by a commission of nine members, three each designated by the two largest political parties, respectively, plus three who would be directly elected by voters.

Leib is not entirely clear with regard to PB voting procedures. He explicitly contemplates that a vote of two-thirds of the "jury," as he calls it, would enact a PB proposal. A vote of at least three-fifths, while insufficient to ratify the proposal, would make it a permissible subject for reconsideration by a later jury, up to a total of three times. Anything less would preclude the PB's reconsideration of the proposal for a period of at least three years, unless reintroduced by a different mechanism. That is, the legislature could always introduce a proposal that had been rejected when put before the PB by popular petition, and vice versa. (Leib 20-21)

What is not clear, however, is how Leib envisions counting the votes. One possibility would be for each of 35 fifteen-member juries to take a vote, and then passage to require approval by two-thirds of the petit juries, or a total of 24 such bodies. The other possibility is that the votes of all 525 PB members will be aggregated in the first instance; the petit jury may be a venue for casting votes, but what would matter is the vote of all jurors, counted individually. Under such a scheme, 350 votes (two-thirds of 525) would be necessary to enact a PB statute, but it would not be necessary for the statute to be approved by two-thirds of the petit 
juries. (For example, the proposal might secure unanimous approval in 20 juries, for a total of 300 votes, plus five votes in each of ten other juries, and none at all in the remaining five.)

Despite this ambiguity and the obvious debatability of any number of details - most obviously, why give the established political parties so much authority over the PB commission? -- Leib's book contains some very great strengths, perhaps most notably a sophisticated argument in favor of mandatory service on PB juries, as opposed to the A-F voluntary model. While A-F eloquently defend Deliberation Day as providing a new opportunity for Americans to enact the ideal of citizenship, Leib is persuasive that the ideals of "legitimacy, popular sovereignty, representativeness, and impartiality" would all be better served by a form of public policy jury duty. ${ }^{1}$ A crude way of stating his view is that citizens in a robust democracy ought to view their contribution to lawmaking as a responsibility, not just as an opportunity.

\section{What legitimates democracy?}

Because the A-F and Leib books appeared on the scene so close together, it is tempting to think of them as two prescriptions for the same set of ailments, differing chiefly in the scope of their ambition. Fans of A-F might be sympathetic to the Leib proposal, but dubious as to its political plausibility. Fans of Leib might acknowledge the A-F proposal as a terrific first step it is hard to imagine that Deliberation Day would not significantly improve our democratic life but argue that Deliberation Day would be too episodic, too detached from actual government policy making to make a significant enough difference in revitalizing American democracy.

$1 \quad$ My own version of a similar proposal appears at Peter M. Shane, "The Electronic Federalist: The Internet and the Eclectic Institutionalization of Democratic Legitimacy," in Peter M. Shane, ed., Democracy Online: The Prospects for Political Renewal THROUGH THE INTERNET 65, 77 (2004). 
In truth, however, A-F and Leib do not perceive the ailments of American democracy in quite the same way. For A-F, the "fundamental right" of a democratic citizen is to "determine the broad direction of public policy through electoral decisions made on the basis of popular deliberation." (A-F 11-12; emphasis added) Elections, that is, in the A-F model of democracy, are the paramount instruments of popular sovereignty. In bewailing what they take to be the sorry state of American democracy, what A-F chiefly bemoan is what they regard as the shallow, ideologically riven, sound-bite driven quality of American electoral politics.

But Leib clearly has reservations about each of the phrases in the A-F formulation that I have italicized. He is explicitly suspicious of what he calls "an excessively plebiscitary model" (Leib 36) of democracy, warning: "Concentration on major elections diverts attention from part of the problem: politics will remain spectatorial and voyeuristic as long as citizens see it as a sporting event." (Leib 38). Relatedly, he thinks it insufficient that citizens be empowered to determine only the broad direction of policy, rather than specific policy content. In this respect, Leib criticizes the Fishkin deliberative polling approach for "suppress[ing] the tremendous potential of the deliberative situation." (Leib 37) Leib aspires instead to "radicalize the use" of citizen juries "and have them engaged in actual institutionalized decision-making about policies, not about politics." (Leib 39) In elaborating on his diagnosis of our "legitimacy deficit," (Leib 4) Leib repeatedly embraces the following formulation that he attributes to Frank Michelman: "Popular political self-government is first of all the ongoing social project of authorship of a country's fundamental laws by the country's people in some nonfictively attributable sense." (Leib 10) Even though this does not mean, for Leib, that every single citizen ought participate in every law-making deliberation, it does mean that citizens should be closely enough involved in 
actual decision making so that "the decisions rendered in their name [can] be fairly imputed to them and their authorship." (Leib 4)

In my judgment, both of these approaches to democratic legitimacy, while valuable, are problematic. On one hand, Leib is persuasive that the electoral link between popular will and the colossal volume of public policy decisions made in the name of "the people" is just too attenuated to sustain any robust claim of popular sovereignty. A presidential election can hope to be a meaningful popular plebiscite over the broad direction of economic policy, foreign affairs policy, military policy, civil rights policy, energy policy, education policy, transportation policy, and on and on, only if, by "broad direction," we mean something like "more-or-lessconservative" or "more-or-less-liberal." Translating such sentiments into popular mandates for almost anything specific is destined to be an exercise in practically pure spin.

On the other hand, Leib's citation of the Michelman formulation is also of dubious utility. First, Michelman is using the idea of "nonfictive" attribution of legal authorship only as it pertains to a society's "fundamental laws," or what he calls its "constitutional essentials"2 not the kind of ordinary lawmaking to which Leib's PB would be devoted. Even in this limited context, however, Michelman admits that his phrase is a "question-begging formulation." ${ }^{3} \mathrm{He}$ uses it to set up a brief, dense meditation on how to understand the relationship between law's provenance and its legitimacy. With due respect to Michelman, a genuine hero of contemporary constitutional thought, I think the phrase is worse than question-begging. Authorship, in this

$2 \quad$ Frank I. Michelman, "How Can the People Ever Make the Laws? A Critique of Deliberative Democracy,” in James Bohman and William Rehg, eds., Deliberative Democracy: Essays on ReAson and Politics 145, 146 (1997).

Id. at 147. 
context, can never be more than a metaphor. Any attribution of legal authorship to "the people" in a mass democracy is going to be, by definition, "fictive." To ask, with regard to a particular society or a particular moment in some society's history, whether the metaphor has more literal truth value than in another place or time, only diverts us from the real question: what do any set of democratic procedures contribute to the moral entitlement of a political regime to demand obedience to its rules and orders?

What's missing, in short, from both A-F and Leib is some deeper discussion of what makes democracy legitimate. Both elections and public deliberations are mechanisms, not ends in themselves. The overarching issue is what these mechanisms are intended to achieve. If we start from the premise that legitimacy is that quality of government that gives those in power the moral authority to impose their will on members of the polity, then, as I have argued elsewhere, democracy's claim to legitimacy rests on two premises. ${ }^{4}$ One is that, as opposed to other systems, it is more likely to facilitate government decision making that at least takes seriously the interests of all persons subject to the decision at issue. Equal respect for all persons is thus one of the moral building blocks of democratic legitimacy. The second is that, as opposed to other systems, democracy empowers individuals with meaningful agency. That is, a democratic regime, properly constituted, allows citizens to experience themselves as autonomous actors free to participate in the determination of their political fate. These are the qualities of government that both elections and public deliberation aim to achieve, the ends to which they function as our most powerful means.

4 Shane, supra note 1 , at 66-73. 
Once this fact is observed, however, it follows that no one decision making mechanism can ever suffice to provide a robust degree of democratic legitimacy. Elections cannot do it because, as Leib would insist, they are too episodic and "spectatorial," even if enriched by A-Fstyle deliberative campaigns. Deliberative citizen consultation cannot do it either because, quite simply, there are too many decisions of consequence that government needs to make in the public interest to permit anything like direct popular involvement on the overwhelming majority of such decisions. What we need, therefore, is some appropriate amalgam of electoral and deliberative mechanisms that, taken all together, hold genuine promise of fulfilling the conditions of democratic legitimacy.

I doubt A-F or Leib would disagree with this point. Taken seriously, however, it seems to lead to the improbable suggestion that neither of their prescriptions is ambitious enough: what we really need is both Deliberation Day and a new branch of government. I would argue, though, that what makes such a prescription seem far-fetched is not the content of the ideas, but rather the authors' chosen venue - our national government. ${ }^{5}$ As the authors duly recognize, there is no obvious political scenario at the national level that would lead to the enactment of their ideas anytime soon, to put it mildly. The ambition to accomplish their agenda at a local level, however, seems significantly more plausible. A version of Deliberation Day focused on mayoral and school board elections, and the appendage of some citizen jury process to our city and county councils, seem to me to be eminently feasible projects - both politically and logistically. Citizens are likely to feel the democracy deficit most sharply in their own

5 To be fair, Leib occasionally speaks of his proposal as a possibility for state government, as well. 
backyards, and the potential efficacy of organizing to do something about it on a local level is far more likely to energize a successful campaign than anything focused on a wider stage.

In sum, both Ethan Leib and the team of Ackerman and Fishkin have made striking contributions to the movement for democratic revitalization. Each recognizes that the quality of our political life rests significantly on the character of our political institutions, and each has proposed a variety of institutional reforms that would genuinely advance, in A-F's words, the project of "realistic utopianism." (A-F 13) It does not derogate from the value of either of these thoughtful, imaginative works to observe that both imply an agenda of serious issues of both principle and logistics that they do not entirely resolve and that advocates of change would need to confront in order to persuade fellow citizens to join in the cause. But I suspect something the reverse is also true: The range of unanswered questions is not so daunting as to preclude exciting local campaigns to turn the A-F and Leib visions into institutional reality in our towns, cities, and counties. If opponents say deliberative democracy is not an ideal susceptible of practical implementation, these books prove otherwise. Their ideas deserve a serious hearing outside the academy. 